\title{
The Validity of Okun's Law in Sri Lanka
}

\author{
Nadeshan Perenparaj* and Gnanachandran \\ *PhD Student, Discipline of Economics, Eastern University, Sri Lanka \\ perinparaj1993@gmail.com
}

\begin{abstract}
The main goal of our research is to find out a relationship between the unemployment rate and the GDP growth rate in Sri Lanka according to Okun's law and to know whether it can still be used as the best rule of thumb. This empirical analysis has employed the difference model, dynamic model, Error Correction Model (ECM) and Vector Error Correction Model (VECM) to validate the relationship between the unemployment rate and economic growth suggested by Okun's Law. The study is based on Quarterly data from 2004 Q1 to 2019 Q4. The results obtained through the application of varies econometric techniques such as Ordinary least square (OLS), Engel-Granger approach and cointegration procedure. The study finds that, Okun's law is supported only by the cointegration analysis as expected by the Okun's law in Sri Lanka. However, all other versions were reported negative Okun's law coefficient signs while these results are not statistically significant. Overall this study is not able to found enough evidence to prove the inverse relationship between unemployment rate and economic growth rate in short run and able to found that Okun's law can still be used as the best rule of thumb to describe the relationship between the unemployment and GDP growth in long term in Sri Lanka.
\end{abstract}

Keywords : Economic Growth, Engel-Granger Approach, Unemployment, VECM

\section{How to Cite}

Nadeshan Perenparaj, N., \& Gnanachandran, G. (2021). The Validity of Okun's Law in Sri Lanka. International Journal of Business, Management \& Economics, 2(2). 118-133. DOI: https: //doi.org/10.47747/ijbme.v2i2.253.

\section{Introduction}

The concepts of economic growth and unemployment are at the beginning the most important variables in the sense that all economies are choosing and implementing economic policies (Soylu et al., 2018). Empirical relationships regarding unemployment have long fascinated economists. For instance, the Phillips curve started life as a simply observed trade-off between unemployment and inflation. But as the theory caught up with the evidence, the Phillips curve emerged as the most important relationship in the way economists viewed the supply-side of the economy and is embedded in all the key macroeconomic models driving policy today (Chamberlin, 2011). Another relationship of interest to economists is that between output and unemployment. Generally, economic growth and low unemployment rate are key macroeconomic policy goals for developing countries like Sri Lanka. Specially, the association

Published by:

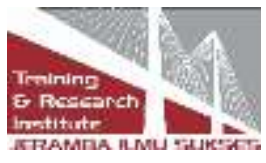


between the real output and the unemployment rate is crucial interest during times of economic recession and recovery. Therefore, the main objective of this research project is to find such an association between the real output and unemployment according to Okun's law and to know whether it can still be used as the best rule of thumb.

The rest of the paper is structured into four more sections. Section 2 describes various theoretical aspects and empirical evidence on the relationship between unemployment and economic growth. Section 3 provides the data and methodology while the main analysis and interpretations of results are presented in the following section. Finally, section 5 summarizes the main findings and conclusions of the analysis.

\section{Literature Review}

\subsection{Economic Growth and Unemployment}

The phenomenon of economic growth is a constant debate among economists, which the most important indicators of the increase in the level of economic and social welfare of a country. Growth theories explain the factors that determine the rate of economic growth of a country. On the other hand, growth theories explain the reasons for differences in income and growth rates among countries. Economists use the gross domestic product (GDP) as the primary measurement of economic growth, which means the market value of final goods and services produced in an economy, stated in the prices over a given period. When people produce and sell their goods through the market they earn income, so then the economy is growing. The "public expense" is put in consideration to investigate the importance of economic growth and shadow economy as well (Luong et al., 2020). And also the strengthening of global technical revolution processes brought into focus the search problem of new models, resources and factors of economic growth (Nurlanova et al., 2020).

Unemployment refers to those who are willing to work from the current wage and cannot find a job. Types of unemployment can be defined as voluntary unemployment, involuntary unemployment, frictional unemployment, cyclical unemployment, seasonal unemployment, technological unemployment, structural unemployment, and hidden unemployment. Initially, economists and society still did not view unemployment as a social problem. It was an individual problem. Unemployment occurs when people are looking for a job and cannot find one. This wasn't a problem in preindustrial farming societies because farmers received net revenue (the income left after all costs have been paid) instead of a wage. The industrial revolution changed the nature of work and unemployment became a problem for society because the industrial revolution was accompanied by a shift to wage labor and a division of responsibilities. In this period, some capitalists took ownership of production and hired others to work for them, paying them wage per hour. These practices marked a significant change in the unemployment problem.

Solow (1956) assumed that employment is an indigenous factor of production. When talking about unemployment, economists usually refer to the "unemployment rate". The unemployment rate is the percentage of people who are willing and able to work, but are not working in the economy. Otherwise, the unemployment rate is determined by dividing the number of unemployed individuals by the number of people in the labor force. The unemployment rate

Published by:

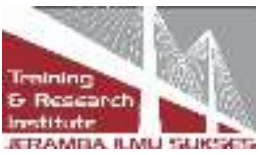

Page 119 
gives a good insight into how much labor is available to increase production and how fast the economy could grow. Generally, the economy is growing as a result of increases in productivity or increases in the number of people choosing to work. Economists translate the target of unemployment rate and target capacity utilization rate (the rate at which factories and machines are operating compared to the maximum sustainable rate at which they could use, it indicates how much capital is available for economic growth) into the target level of potential output.

To explore what changes in the unemployment rate will have on output we use Okun's rule of thumb (Colander, 2001). Okun summarized the inverse relationship with a regression that related change in the unemployment rate to changes in real output growth. This inverse relationship, often termed Okun's Law, appears in forecasting models used by central banks, governments, and the private sector (Mary et al., 2015). Wulandari et al. (2019) stated that the labor force women and children tend to show the existence of a higher unemployment rate than older men. Therefore, when inflation is at a certain level, unemployment is higher.

Sri Lanka has witnessed a considerable reduction of its unemployment rate over the past decades. Annual average GDP growth in the range of 5 per cent has helped to generate employment in Sri Lanka. However, employment growth is explained more by the growth in public-sector employment and informal types of employment than informal and private sector employment. Furthermore, unemployment remains high for females, youth and educated (Dushni \& Nisha, 2011).

\subsection{Okun's Rule of Thumb}

Okun's (1962) seminal paper regarding the unemployment-output relationship considers the measurement of potential output. Okun believed that the potential output should not be defined as the maximum output the economy could (unconditionally) produce. Instead, he argued that the potential should be measured at full employment, which he believed that a four percent unemployment rate is a reasonable target to achieve full employment without inflationary pressure or the level of the non-accelerating rate of unemployment (NAIRU). Consequently, at the business cycle frequency, the deviations of unemployment from a level such as the NAIRU could be correlated with the deviations of output from its trend (Owyang \& Tatevik, 2012).

Okun (1962) empirically proved the inverse relationship between the unemployment rate and the potential output, depending on the participation in the workforce, the duration of work and the change in productivity. This rule of thumb is based on the fact that the increased workforce must produce more goods and services. According to this fact, the unemployment rate declined in the years when the real growth rate was high, whereas the unemployment rate increased in the years when the real growth rate remained low or even negative. Okun's rule of thumb states that a 1 percentage point change in the unemployment rate will cause the output to change in the opposite direction by 2 percent. Also, he presented two empirical relationships between the unemployment rate and the real output, namely, the difference approach and the gap approach.

\subsubsection{The difference/changes version}

This version captures how changes in the real output affect the unemployment rate. The

Published by:

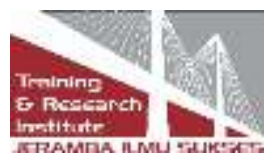


theoretical underpinning of Okun's Law in this section comes from production theory. It is straightforward to map changes in the unemployment rate to changes in the inputs used by firms relatively directly in the case of labor and indirectly for other inputs (Mary et al., 2011). Arthur Okun noted in this version that, quarterly changes in the unemployment rate were related to quarterly growth in the real gross national product (Chamberlin, 2011). The Okun's difference version equation is given below,

$\Delta \mathrm{u}_{\mathrm{t}}=\alpha+\beta \Delta \mathrm{GNP}_{\mathrm{t}}$

In the above equation (01), $\Delta$ sign denotes the time difference operator, ut is percentage changes in the unemployment rate, GNP is percentage changes in real GNP, $\alpha$ is constant that shows a mean change in the unemployment rate when the economy does not grow. The coefficient $\beta$ is Okun's law coefficient (OLC).

\subsubsection{The gap version}

Another main version used by Okun is the gap version approach. In this version deviations in the unemployment rate were related to deviations in GDP from its potential. Especially in this approach, certain exponential paths of potential output are chosen based on the agreement that this potential GNP should be equal to actual GNP when the unemployment rate level is four per cent in the economy. The gap version regression equation is given below,

$\mathrm{u}_{\mathrm{t}}=\mathrm{a}+\mathrm{b} *($ gap between actual output and potential output $)$

\subsubsection{Other Versions of Okun's Law}

Besides, we consider an extension of the original Okun's Law that allows the current and past values of output growth to affect the changes in the unemployment rate differently. The dynamic version of Okun's Law included the current and past values of economic growth rate and past changes in the unemployment rate into the model as given below,

$$
\Delta \mathrm{u}_{\mathrm{t}}=\alpha_{1}+\beta 1 \Delta \mathrm{y}_{\mathrm{t}}+\beta_{11} \Delta \mathrm{y}_{\mathrm{t}-1}+\beta_{12} \Delta \mathrm{y}_{\mathrm{t}-2}+\Upsilon_{11} \Delta \mathrm{u}_{\mathrm{t}-1}+\Upsilon_{12} \Delta \mathrm{u}_{\mathrm{t}-2}+\mathrm{e}_{\mathrm{lt}}
$$

The dynamic version is the distributed lag version of the familiar difference specification in equation (01). We refer to this formulation of Okun's Law as a "Dynamic" specification. In this case, the change in the unemployment rate is determined jointly with lags of it and lagged and current changes in output growth. Otherwise, the production function approach explains the effects of a combination of technology, labor and capital are observed in the production of output. The production function version can be expressed as follow,

$$
\mathrm{Y}=\alpha(\mathrm{k}+\mathrm{c})+\beta(\Upsilon \mathrm{n}+\delta \mathrm{h})+\tau
$$

Where, $\mathrm{Y}$ is economic growth or output, $\mathrm{k}$ is the capital input, and $\mathrm{c}$ is its utilization rate, $\mathrm{n}$ represents the number of workers, $h$ is the number of hours worked, $\alpha$ and $\beta$ are output elasticities, $\Upsilon$ and $\delta$ are the combinations of workers and weekly hours to the total labor input and $\tau$ is a disembodied technology factor. The major drawback of this method is that the measurement of both capital and technology is difficult.

Published by:

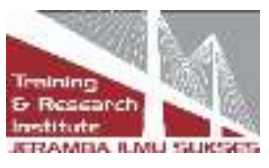




\subsection{Related Literature}

In 1962, Arthur Melvin Okun posited an empirical relationship between the change in the unemployment rate and real output growth. Since then, the media, policymakers, pundits and intermediate macroeconomics students have used the so-called Okun's Law as a rule of thumb to relate changes in unemployment to changes in output growth. However, some studies have suggested that the relationship has not been stable over time. Furthermore, the slow recovery of U.S unemployment relative to output after the Great Recession has led some to question whether Okun's Law has changed permanently (Owyang \& Tatevik, 2012). As many of the reduced-form relationships build strictly on associations and not causation, Okun's law appears to vary depending on the sample period studied and Okuns Law rarely appears in modern macro studies. However, after 1962, economists and researchers have been investigated Okun's Law to confirm the relationship between the unemployment and output for various periods of times for various countries. Some of the studies explaining the relationship between growth and unemployment rates are presented below in chronological order.

Arthur Okun (1962) was the first economist who developed an economic model to explain the empirical relationship between unemployment and economic growth. He used quarterly data from 1947 to 1960 and used OLS as a key methodology to prove the inverse relationship between unemployment and economic growth. This inverse relationship between the two important economic variables is famously known as Okun's Law and since then it has been used as the best rule of thumb. (Barreto \& Howland, 1993) stated that the coefficients accepted in Okun's are not valid for the Japanese economy. They analyzed the 1953-1982 period in Japan with regression estimation. Also, Moosa (1997) found the lowest Okun's coefficient for Japan and the highest coefficient for North America for the period of 1960-1995.

In Europe's experience, Zonzilos (2000) found that if Greece output increases by 1 percent unemployment will decrease by 0.28 percent. His estimation is covered the period from 1965 to 1999. However, Zagler (2003) stated that there is a co-integration between economic growth and unemployment in the long run and there is a positive relationship between these variables in European economies including France, Germany, Italy and the UK. Zagler investigated Okun's Law using VECM as a key methodology. (Harris \& Silverstone, 2001) have analyzed unemployment and output levels of relation. In this study, seven OECD (Organisation for Economic Co-operation and Development) countries were discussed. Empirical evidence shows that there is no long-run relationship between the two variables. Muscatelli and Tirelli (2001) also examined the unemployment and economic growth for the OECD countries, over the period 1955-1990 using the structural VAR model and found a negative relationship between these variables.

Knotek (2007); Knotek II (2007) tested the validity of Okun's Law in the United States from 1948 to 2007 with Cointegration Analysis and argues Okun's Law can be used as a simple rule of thumb to determine how much unemployment would induce output growth. He estimated the unemployment rate every quarter and he introduced the past level of output, the current level of

Published by:

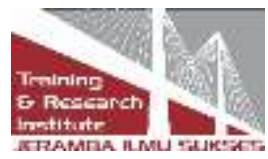

Page 122 
output and past level of employment to analyze the effects of economic growth on unemployment in the gap version. He found a negative correlation between GDP growth and unemployment. Lal et al., (2010) have shown the existence of both long-term and short-term relationships between economic growth and unemployment in Bangladesh, China, India, Pakistan and Sri Lankan economies in the1980-2006 periods. And also Balakrishnan et al. (2010) in turn used Okun's Law as an organizing framework to explain unemployment dynamics for a group of advanced countries during the latest recession. Lee (2000) tested Okun's Law in Some Asian Countries with Cointegration Approach. They have used time series annual data during the period 1980 to 2006 and used Engle Granger cointegration technique to find the long-run relationship between variable and error correction mechanism for short-run dynamic. They concluded that Okun's Law interpretation may not be applicable in some Asian developing countries.

The relationship between changes in output and the unemployment rate is of significant interest around times of recession and economic recovery (Chamberlin, 2011c). He examined various aspects of this relationship over time, across various constituents of the labor market for different countries. He also explores the interactions between changes in the unemployment rate with the household population, economic activity rate, average hours and labor productivity in accounting for recent output movements in the UK economy and how these compare to previous recessions and recoveries. He estimated Okun's Law by gender and age structure as well. Unlike usual estimation techniques, Islas-Camargo and Cortez (2011) follow Clark (1989) to estimate the correlation between the transitory components of unemployment and output as part of a system of correlations between the permanent and transitory components of both series. This model provides a better estimate of the Okun's Law and found that the Okun's coefficient for the Mexican economy is significantly lower than previous estimations and unbiased and efficient estimations.

Over the years, Okun's Law has been predominantly used as a rule of thumb to predict how changes in output will feed through to the labor market. Conventional wisdom said 'that for every 2 percent drop in the real gross domestic product (GDP) below trend leads to a 1 percentage point rise in the unemployment rate'. However, this relationship has proved to be unstable over time. But, whilst the breakdown in the Phillips curves during the stagflation of the 1970s lead to the development of its theoretical underpinning, the same did not happen for Okun's Law (Chamberlin, 2011d). Abdullah and Anees (2014) find out a relationship between the unemployment rate and the GDP growth rate as proposed by Okun. The paper also focuses on the short-run and long-run relationship between these two variables. Time-series econometric techniques are applied on each period to find an association between unemployment rate and GDP growth rate including Augmented Dickey-Fuller (ADF) test for stationary analysis, EngleGranger test of cointegration and Johansen test of co-integration for co-integration analysis, vector autoregressive model (VAR) and vector autoregressive model (VECM) for finding interdependencies between variables. Finally, they estimated a difference version of Okun's Law regression equation. But no contemporaneous impact on the unemployment rate by the GDP growth rate.

Published by:

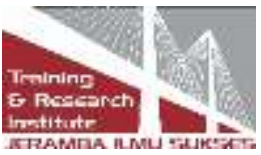


Laurence et al., (2017) investigated how well Okun's Law fits short-run unemployment movements in the United States since 1948 and in 20 advanced economies since 1980. They estimated Okun's Law with both annual and quarterly data and found that Okun's Law is a strong relationship in most countries and one that is fairly stable over time. They used the term "potential output" for long-run output and the "natural rate" for long-run unemployment. Potential output is determined by the economy's productive capacity and it grows over time as a result of technological change and factor accumulation. The long-run level of employment and the natural rate of unemployment are determined by the size of the labor force and by frictions in the labor market. When the output is at its long-run level, employment and unemployment are also at their long-run levels. Soylu et al., (2018) investigate the relationship between economic growth and unemployment in Eastern European Countries for the period of 1992-2014 within panel data framework. In this paper, this relationship has been examined in the context of Okun's Law. Panel Unit Root, Pooled Panel OLS and Panel Johansen Co-integration tests are applied respectively. The results showed that the economic growth and unemployment series are stationary at first level, unemployment affected positively by economic growth in long run in other words 1 percent rise in GDP will fall the unemployment rate by 0.08 percent based on Okun's coefficient for Eastern European Countries.

Prabagar (2015) investigated the equilibrium relationship between the unemployment rate and economic growth in the context of the Sri Lankan economy over quarter 1, 2003 to quarter 1, 2015. He employed the difference model, dynamic model, error correction model and vector error correction model to validate the relationship between the unemployment rate and economic growth suggested by Okun's Law. This empirical study specified that there are a short-run and long-run equilibrium relationship between the unemployment rate and economic growth in the Sri Lankan economy. However financial crisis impacts labor markets around the world and Okun's Law faced serious challenges. As a result, various studies have shown positive economic growth with no improvement in unemployment, which is famously known as jobless growth (Abdullah \& Anees, 2014).

However, I was unable to find more literature about the analysis of the relationship between the unemployment rate and economic growth in Sri Lanka relation to Okun's Law. Sri Lanka has witnessed a considerable reduction of its unemployment rate over the past decade. Annual average GDP growth in the range of 5 percent has helped to generate employment. However, unemployment remains high for females, for youth and the educated. The literature confirmed that studies based on economic growth and unemployment in emerging countries like Sri Lanka is limited to a few recent studies. Hence, this study attempt to find out the relationship between unemployment and economic growth in Sri Lanka based on Okun's Law.

\section{Methodology}

\subsection{Data}

Our analysis relies on revised data observed at a quarterly frequency. The variables are seasonally adjusted and standardized in percentage points. The sample period includes $2004 \mathrm{Q} 1-$ 2019 Q4. Economic growth is measured as the quarter-over-quarter growth rate of real GDP.

Published by:

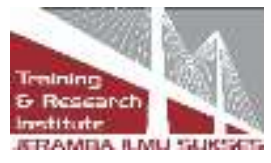


Data from the Macroeconomic Chart Pack of the central bank of Sri Lanka and international financial statistics are used for real GDP growth and the civilian unemployment rate respectively. Due to tsunami and other reasons, the labor force survey was not implemented in 2005 every quarter and 2011 Q4 and 2012 Q1 as scheduled. Hence we got Interpolate data series for quarterly unemployment rate series to test the validity of the rule of thumb.

\subsection{Model Specifications}

Our empirical analysis has employed the difference model, dynamic model and error correction model and vector error correction model to validate the relationship between the unemployment rate and economic growth suggested by Okun. Difference version estimation is most suitable for this empirical analysis. The expected model of difference version of Okun's Law is given below,

$$
\Delta \mathrm{u}_{\mathrm{t}}=\alpha+\beta \Delta \mathrm{GDP}_{\mathrm{t}}+\varepsilon_{\mathrm{t}}
$$

Where, $\Delta u t$ is the change in the unemployment rate, $\Delta$ GDPt is the change in the GDP growth rate, $\beta$ is the Okun's Law Coefficient (OLC), $\alpha$ is the unemployment rate when the economy does not grow (constant) and $\mathrm{Et}$ represents the error term where $\mathrm{Et} \sim \mathrm{N}(0, \sigma 2)$ and $\mathrm{t}=1 \ldots . . \mathrm{T}$. To estimate the difference version of Okun's Law we used Ordinary Least Square method (OLS).

Equation (05) implies that some relevant variables have been omitted from the right side of the equation. Therefore, we used a dynamic version of Okun's Law in estimating the relationship between GDP growth rate and unemployment rate. The dynamic version includes more explanatory variables such as lagged variables of the unemployment rate and GDP growth. The dynamic version empirical model can be expressed as follows:

$$
\Delta \mathrm{ut}=\alpha+\beta 1 \Delta \mathrm{GDPt}+\beta 2 \Delta \mathrm{GDPt}-1+\beta 3 \Delta \mathrm{ut}-1+\mathrm{et}
$$

Where $\Delta$ GDPt-1 and $\Delta$ ut-1 are lagged value of economic growth and unemployment rate respectively. To eliminate serial correlation we use the past value of unemployment change as an independent variable.

\subsection{Varies Time Series Procedures}

The stationary concept is important in the time-series analysis because if a time series is nonstationary, then all typical results of classical regression analysis are not valid and therefore the regression would be a false or fake regression (Gujarati, 2003). Both equation 05 and 06 assumes that the variables are unit root level or non-stationary at level form while stationary at first difference. Hence, both regression models may be spurious. To avoid spurious regression this paper also used another model, which is called Error Correction Method (ECM) for estimating the coefficient of Okun using the procedure of Engle-Granger. Engle-Granger proposed a residual-based cointegration test. If residual series is stationary at it level form that concludes both variables are cointegrated and have a long-run relationship between themselves. The ECM model is described as follows,

$$
\Delta \mathrm{GDP}_{\mathrm{t}}=\alpha+\beta 1 \Delta \mathrm{U}_{\mathrm{t}}+\beta 2 \mathrm{R}_{\mathrm{t}-1}+\mathrm{e}_{\mathrm{t}}
$$

Where $\Delta$ GDPt and $\Delta \mathrm{u}_{1}$ are economic growth and unemployment in the first difference, $\alpha$ is the

Published by:

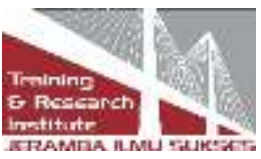


intercept, $\beta_{1}$ is the short-run coefficient and $\mathrm{R}_{\mathrm{t}-1}$ is error correction term, which, should be negative after estimation.

Finally, this paper used the Vector Error Correction Model (VECM) for testing the long-run causality and the short-run causality between GDP growth rate and unemployment rate case of Sri Lanka. VECM commonly used with Johansen multivariate cointegration test. For cointegration analysis, both variables should be integrated in the same order. Hence, identification of integration is base for cointegration analysis. Otherwise, all the variable should be integrated with order one or should be stationary at first difference. Thus, before estimate the VECM we employed the unit root test to get information about the stationary of each time series. Our analysis consists of two-time series which are economic growth and unemployment, so we can get two estimations similarly in VECM. The expected VECM equations are as follows,

$$
\begin{aligned}
& \mathrm{GDP}_{\mathrm{t}}=\beta_{0}+\beta_{\mathrm{i}} \sum_{i=1}^{k} \quad U_{\mathrm{t}-\mathrm{i}}+\Upsilon_{\mathrm{i}} \sum_{i=1}^{k} \quad G D P_{\mathrm{t}-\mathrm{i}}+\mathrm{e}_{1 \mathrm{t}} \\
& \mathrm{U}_{\mathrm{t}}=\alpha_{0}+\alpha_{\mathrm{i}} \sum_{i=1}^{k} \quad U_{\mathrm{t}-\mathrm{i}}+\delta_{\mathrm{i}} \sum_{i=1}^{k} \quad G D P_{\mathrm{t}-\mathrm{i}}+\mathrm{e}_{2 \mathrm{t}}
\end{aligned}
$$

Where, GDPt and ut are economic growth and unemployment, $\beta_{0}$ and $\alpha_{0}$ are the intercepts, $\mathrm{GDP}_{\mathrm{t}-1}$ and $\mathrm{U}_{\mathrm{t}-1}$ arelagged values of both variables and e1t and $\mathrm{e} 2 \mathrm{t}$ are random error term with zero mean.

Furthermore, this paper used some sophisticated time-series tests, namely, causality test and Impulse Response Function for testing the time series property of the models and imposed some key violations test as well.

\section{Results and Discussions}

Our analysis begins with the unit root test. Table 1 explains the result of Augmented DickeyFuller (ADF) stationary tests of the GDP growth rate and unemployment rate. Unit root test based on Swarch info criterion and does not consider Trent or constant. Here our decision is based on alpha value and probability value. If the alpha values smaller than the probability value at 1 per cent, 5 per cent or 10 per cent significance level, then the null hypothesis is accepted. [H0: series has a unit root or the series is not stationary at its level].

Table 1: Unit root test Results

\begin{tabular}{|l|c|c|}
\hline \multicolumn{1}{|c|}{ Variable } & At level & $\begin{array}{c}\text { At 1 }{ }^{\text {st }} \\
\text { difference }\end{array}$ \\
\cline { 2 - 3 } & $\mathrm{P}$ - value & $\mathrm{P}$ - value \\
\hline $\begin{array}{l}\text { Economic growth rate } \\
\text { (GDP growth rate) }\end{array}$ & 0.190 & $0.000^{*}$ \\
\hline Unemployment rate & 0.087 & $0.000^{*}$ \\
\hline
\end{tabular}

Note: The superscript * denotes rejection of null hypothesis at $1 \%$ significant level.

The results show that p-value of both variables are greater than 5 per cent significant level at its natural level form. This can be concluded that both variables are non-stationary at level form. However, the p-value of both variables is smaller than 5 per cent significant level at the first

Published by:

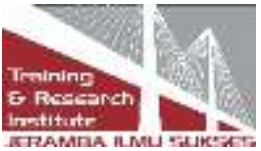


difference and depicts that the GDP growth and unemployment rate becomes stationary after first difference. Also, this result concludes that the long-run monetary model is to use cointegration procedures. Our empirical analysis consists of four different estimations of Okun's law.

The difference model and dynamic model are estimated in the OLS method. The estimation of different Version (equation 05) of Okun's Law is shown in Table 2.

Table 2: The estimation of different Version of Okun's Law

\begin{tabular}{|l|c|c|c|}
\hline \multicolumn{1}{|c|}{ Variable } & $\begin{array}{c}\text { Coefficie } \\
\text { nt }\end{array}$ & t-Statistic & Prob. \\
\hline $\begin{array}{l}\text { D(GDP_Growth } \\
\text { Rate) }\end{array}$ & -0.018 & -0.939 & 0.351 \\
\hline Constant & -0.058 & -1.194 & 0.236 \\
\hline R-squared & AIC & 0.972 \\
\hline Prob (F-statistic) & D-W & 2.280 \\
\hline
\end{tabular}

Based on these results it is clear that there is a negative relationship between the GDP growth rate and the unemployment rate because GDP coefficient has a negative sign. However, this Okun's coefficient is insignificant at 5 per cent level thus the different versions of Okun's model is insignificant at 5 percent level. Secondly, we estimated the Dynamic version of Okun's law and explained Okun's coefficient. The results of the Dynamic version are shown in Table 3.

Table 3: Estimation of Dynamic version of Okun's Law

\begin{tabular}{|l|c|c|c|}
\hline Variable & Coeff. & t-Stat & Prob. \\
\hline GDP growth rate & -0.044 & -1.565 & 0.123 \\
\hline GDP growth rate (-1) & 0.006 & 0.234 & 0.815 \\
\hline Unemployment Rate (-1) & 0.934 & 21.653 & $0.000^{*}$ \\
\hline C & 0.474 & 1.981 & $0.052^{* * *}$ \\
\hline R-squared & AIC & 1.030 \\
\hline \multicolumn{2}{|l|}{ Prob (F-statistic) } & DW-stat & 2.424 \\
\hline
\end{tabular}

Note: The superscripts $*$ and $* * *$ denote the significance of the variables at $1 \%$ and $10 \%$ respectively.

This estimation concluded that GDP coefficient has a negative sign but it is not significant. GDP lagged variable also has an insignificant relationship with unemployment. This signifies that there is no significant relationship between unemployment and GDP growth rate based on dynamic version of Okun's law. However, there is a positive relationship between the Unemployment rate and its lagged value at 1 per cent level while the overall model significant at 1 per cent level. The constant value of 0.474964 shows mean change in the unemployment rate when the economy does not grow.

The third part of the empirical analysis of this study is estimating the Error Correction Model (ECM) based on Engel- Granger approach. Engle and Granger (1987) recommend a two-step procedure for cointegration analysis. A test of cointegration is a test of whether residual series is stationary. This is determined by ADF tests on the residuals. The stationary test of residual of equation (05) is as follows, see Table 4.

Published by:

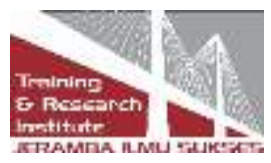


Table 4: the result of Unit root test for residual series

\begin{tabular}{|c|c|c|c|}
\hline \multicolumn{4}{|c|}{ Null Hypothesis: Residual series has a unit root } \\
\hline \multicolumn{4}{|c|}{ Exogenous: Constant } \\
\hline \multicolumn{4}{|c|}{ Lag Length: 0 (Automatic - based on SIC) } \\
\hline \multirow{2}{*}{\multicolumn{2}{|c|}{ ADF test statistic }} & $\mathrm{t}$-Statistic & Prob.* \\
\hline & & -9.995 & $0.000 *$ \\
\hline \multirow[t]{3}{*}{$\begin{array}{c}\text { Test critical } \\
\text { values: }\end{array}$} & $1 \%$ level & -3.540 & \\
\hline & $5 \%$ level & -2.909 & \\
\hline & $10 \%$ level & -2.592 & \\
\hline
\end{tabular}

Note: The superscript $*$ denotes rejection of null hypothesis at $1 \%$ significant level.

According to this result, the residual of difference version equation is stationary at its level form and identified that GDP growth and unemployment rate are cointegrated and they have a longrun relationship. This residual unit root test allows re-estimating the difference version equation with an error correction mechanism. The results of the error correction model are shown in Table 5 .

Table 5: Estimation of the error correction model

\begin{tabular}{|l|c|c|c|}
\hline \multicolumn{4}{|c|}{ Method: Least Squares (Engel-Granger method) } \\
\hline Variable & Coefficient & t-Statistic & Prob. \\
\hline DEG & -0.015 & -0.758 & 0.451 \\
\hline ect (-1) & -0.070 & -2.006 & $0.049^{* *}$ \\
\hline C & -0.057 & -1.205 & 0.232 \\
\hline \multicolumn{2}{|c|}{ Prob(F-statistic) } & DW- stat & 2.260 \\
\hline
\end{tabular}

Note: The superscript $* *$ denotes the significance of the variable at $5 \%$ significant level.

Based on Engel Granger approach, short-run coefficient value became negative (-0.01551) but it is not significant. This concludes that the GDP growth rate has no short-run equilibrium relationship with the unemployment rate. However, the error correction term (ECT) has became negative and significant at 5 per cent significant level. That means error term corrects its previous period disequilibrium at the speed of 0.07 per cent quarterly. Here we can consider the ECT as Okun's coefficient. Hence ECM concluded that there is no short-run equilibrium relationship between GDP growth and the unemployment rate and the same time both variables have a long-run equilibrium relationship. There is another way to confirm the long-run relationship is VECM with cointegration analysis.

Finally, we analysed GDP growth and unemployment rate with VECM which explains both the short-run and long-run relationships. For Vector Error Correction Model we choose one lag based on Likelihood ratio, final prediction error, Akaike info criterion and Hannan-Quinn info

Published by:

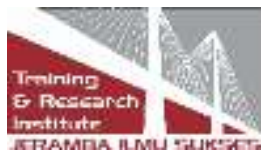


criterion. At the same time, we found cointegration between the unemployment rate and GDP growth rate through the Johansen cointegration procedure. Both trace test and the maxeigenvalue test indicates two cointegrating equations at the 0.05 level. This estimation confirmed that there is a long-run relationship between the unemployment rate and economic growth in Sri Lanka. According to Johansen cointegration procedure and VECM estimations, the long-term cointegrating equation is as follows.

Unemployment ratet $=9.167928-0.719975$ GDP growth ratet

The t-statistics of Okun's law coefficient is [3.07005] indicated that the GDP growth rate has a significant inverse relationship with the unemployment rate in the long run in Sri Lanka. According to the cointegration equation, one per cent increase in the GDP growth rate cause 0.72 percentage declines in the unemployment rate in the long run. Furthermore, VECM estimations confirmed the validity of Okun's law in Sri Lanka when the Okun' law coefficient becomes statistically significant with a negative sign. VECM explain the short-run dynamics as well, the estimations of VECM equations (04) and (05) are below,

$\mathrm{GDPt}=-0.10915-0.586 \sum_{i=1}^{2} \quad U \mathrm{t}-\mathrm{i}+-0.3059 \sum_{i=1}^{2} \quad G D P \mathrm{t}-\mathrm{i} *-0.218862$

$\mathrm{Ut}=0.08433-0.26378 \sum_{i=1}^{2} \quad U \mathrm{t}-\mathrm{i} * *-0.0866 \sum_{i=1}^{2} \quad G D P \mathrm{t}-\mathrm{i}-0.06287 *$

(Note: The superscripts $*$ and $* *$ denote the significance of the variables at $1 \%$ and $5 \%$ respectively and the error correction terms are provided in bold letters)

Based on these equations it is confirmed that there is an inverse relationship between the unemployment rate and GDP growth in both equations. This means one percentage increase unemployment rate leads to 0.586 percentage decrease in Sri Lanka's GDP growth. Similarly, one per cent increase in Sri Lanka's GDP growth is leading to 0.08663 percentage decrease in the unemployment rate in the short run. Error correction term in the second equation has become statistically significant with a negative sign. According to the ECT coefficient of -0.062873 indicates that around $6 \%$ of disequilibrium in the unemployment rate in the short-term is corrected quarterly. To be more specific, it takes more than four years to correct short-term disequilibrium and to restore the long-term equilibrium of the unemployment rate in Sri Lanka. Furthermore, this paper analysed the causal relationship and impulse response function for the unemployment rate and GDP growth series. The granger causality test clarified how these variables affect (drive) each other. The VEC Granger Causality/Block Exogeneity Wald Tests results are shown in Table 6.

Table 6: Summary of causality test

\begin{tabular}{|l|l|l|}
\hline Null hypothesis (H0) & P-value & Decision \\
\hline $\begin{array}{l}\text { GDP growth does not } \\
\text { Granger cause the } \\
\text { unemployment rate }\end{array}$ & 0.338 & H0 Accepted \\
\hline $\begin{array}{l}\text { the unemployment rate does } \\
\text { not Granger Cause GDP } \\
\text { growth rate }\end{array}$ & 0.450 & H0 Accepted \\
\hline
\end{tabular}

Published by:

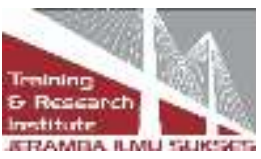


From these results, there was no causal relationship between the unemployment rate and GDP growth rate in Sri Lanka. However, the Impulse response function is supported to prove the inverse relationship between the unemployment rate and GDP growth in Sri Lanka as shown in Figure 1.

\section{Response of UNEM_I to EG Innovation using Cholesky (d.f. adjusted) Factors}

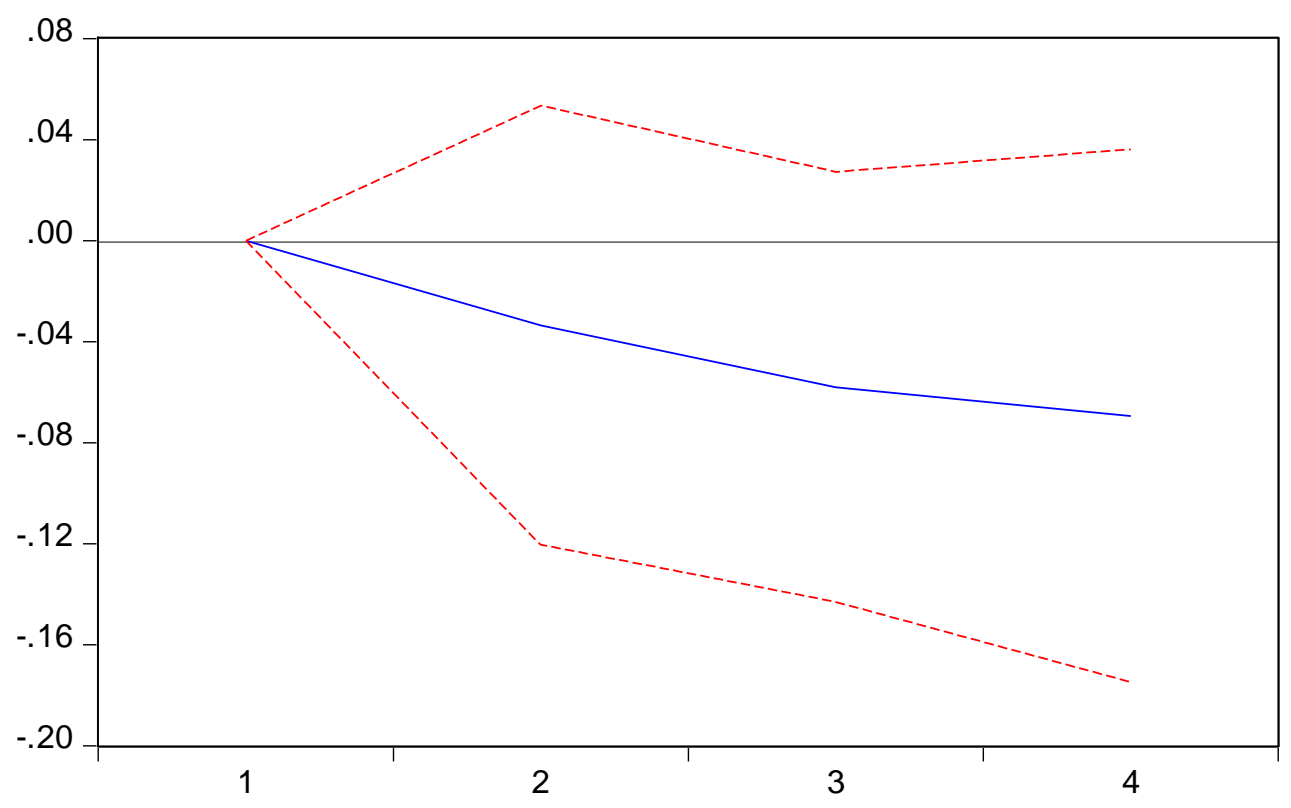

Figure 1: Impulse Response Function

Based on Impulse Response Function it is clear that there is a significant inverse relationship between the unemployment rate and GDP growth rate from the beginning. Which means a one unit standard deviation shock of GDP growth made an inverse impact on the unemployment rate in the long term and It will take a long period to reach the equilibrium level.

The following Table 7 is summarizing some of the important residual-based Diagnostic test results for each model.

Table 7: Summary of the Diagnostics Tests

\begin{tabular}{|l|c|c|c|}
\hline \multicolumn{4}{|c|}{ Diagnostic test (p-value) } \\
\hline Models & $\begin{array}{c}\text { Normality } \\
\text { test }\end{array}$ & $\begin{array}{c}\text { AC-LM } \\
\text { test }\end{array}$ & $\begin{array}{c}\text { Het. } \\
\text { Tests }\end{array}$ \\
\hline Difference version & 0.612 & 0.186 & 0.985 \\
\hline Dynamic Version & 0.162 & 0.005 & 0.953 \\
\hline ECM & 0.038 & 0.083 & 0.811 \\
\hline VECM & 0.023 & 0.563 & 0.075 \\
\hline
\end{tabular}

Basing on the table above, it is now clear that Difference version estimation is stable. Its means

Published by:

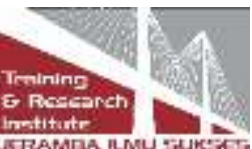


estimation is normally distributed, serial uncorrelated with equal variance and the parameters are stable. Dynamic version estimations satisfy the normality test and Heteroscedasticity test while suffering from serial correlation. Finally, ECM and VECM are not suffering from serial correlation and Heteroscedasticity problem however; residuals of these both models are not multivariatly normal. These pieces of evidence are not enough to validate the presence of Okun's law in Sri Lanka.

\section{Conclusion}

The concepts of economic growth and unemployment are most important in the sense that all economies are choosing and implementing economic policies. Thus, when an economy is growing, unemployment is usually falling; when an economy is in recession unemployment is usually rising. Arthur Melvin Okun (1962) summarized the inverse relationship from changes in the unemployment rate to changes in real output growth by using regression.

Sri Lanka has witnessed a considerable reduction of its unemployment rate over the past decade. The literature confirmed that studies based on economic growth and unemployment in emerging countries like Sri Lanka are limited to a few recent studies. Hence, this study attempt to find out the relationship between unemployment and economic growth and also test the validity of Okun's law in Sri Lanka. This empirical analysis has employed the difference model, dynamic model, Error Correction Model (ECM) and Vector Error Correction Model (VECM) to validate the relationship between the unemployment rate and economic growth suggested by Okun's Law. For this purpose, quarterly data from 2004 Q1 to 2019 Q4 are used in this empirical analysis. This study is structured as four different models and five equations to prove the inverse relationship between the unemployment rate and economic growth rate and check the validity of Okun's law in Sri Lanka.

All the models proved that there is an inverse relationship between the unemployment and GDP growth in Sri Lanka as we assumed by Okun's Law. Especially, difference version and dynamic version of Okun's law shows a negative relationship but the result is not significant at 5 per cent significant level. This study analysed both short-run and long-run relationship between the unemployment rate and economic growth rate through Engel-Granger approach and Vector Error Correction Model. These two models found longterm cointegration between the unemployment rate and economic growth rate in Sri Lanka.

VECM proved the statistically significant negative relationship while Engel Granger approach reported an insignificant negative relationship between the unemployment rate and GDP growth rate in Sri Lanka. However, Error correction term in both these models reported the correct sign and became statistically significant. Furthermore, the Impulse Response Function also satisfied the negative relationship between the unemployment and economic growth suggested by Okun in Sri Lanka. Overall this study implies that Okun's Law can still be used as the best rule of thumb to describe the relationship between the unemployment and GDP growth only in long term in Sri Lanka.

\section{References}

Abdullah, A., \& Anees, A. (2014). Okun's Law: Can It Still Be a Best Rule Of Thumb? (A Time Series Analysis). Pomona: California State Polytechnic University.

Published by:

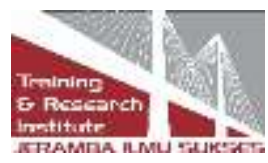


Balakrishnan, R., Das., \& Kannan,P. (2010). Unemployment Dynamics during Recessions and Recoveries: Okun's Law and Beyond. International Monetary Fund. Retrieved from: https://www.elibrary.imf.org/view/IMF081/10502-9781589069152/105029781589069152/ch03.xml?rskey=C8Tcqf $\&$ result $=45 \&$ redirect $=$ true

Barreto, H., \& Howland, F. (1993). There are two Okun's law relationships between output and unemployment. Crawfordsville: Wabash College.

Chamberlin, G. (2011). Okun's Law revisited. Economic \& Labour Market Review, Office for National Statistics, 104-134.

Colander, D. C. (2001). Economics (4th ed.). New York, NY: Irwin/McGraw-Hill.

Dushni, W., \& Nisha,A. (2011). Macroeconomic policy for full and productive employment and decent work for all: Sri Lanka country study. Employment Sector Employment Working Paper No.110, 01-63.

Gujarati, D. N. (2003). Basic Econometrics (4th ed.). New York,NY: McGraw-HiII/lrwin.

Harris, R., \& Silverstone, B. (2001). Testing for asymmetry in Okun's law: A cross-country comparison. Economics Bulletin, 5(2), 1-13.

Islas-Camargo, A., \& Cortez, W. W. (2011). Revisiting Okun's law for Mexico: an analysis of the permanent and transitory components of unemployment and output. Munich Personal RePEc Archive, pp. 01-29. Available at: https://mpra.ub.uni-muenchen.de/30026/

Knotek , E. S. (2007). How useful is Okun's law? Economic Review-Federal Reserve Bank of Kansas City, 92(4), 73-103. Available at: https://www.kansascityfed.org/publicat/econrev/pdf/4q07knotek.pdf

Knotek II, E.S. (2007). How useful is Okun's law? Economic Review, 92(4), 73-103.

Lal, I., Muhammad, S. D., Jalil, M. A., \& Hussain, A.(2010). Test of Okun's law in some Asian countries cointegration approach. Journal of Scientific Research, 40(1), 73-80.

Laurence,B., Daniel, L., \& Prakash, L. (2017). Okun's Law: Fit at 50? Journal of Money, Credit and Banking, 49(7), 1413-1441.

Lee, J. (2000). The robustness of Okun's law: Evidence from OECD countries. Journal of Macroeconomics, 22(2), 331-356. https://doi.org/10.1016/S0164-0704(00)00135-X.

Luong, T.T.H., Nguyen,T.M., \& Nguyen,T.A.N. (2020). Rule of Law, Economic Growth and Shadow Economy in Transition Countries. Journal of Asian Finance, Economics and Business, 7(4), 145-154. https://doi.org/10.13106/jafeb.2020.vol7.no4.145

Mary, C., Daly, J.G., Fernald, S., \& Nechio, J.F. (2015, March 30). Output and Unemployment Dynamics. Federal Reserve Bank of San Francisco, pp. 1-54.

Muscatelli, V. A., \& Tirelli, P. (2001). Unemployment and growth: some empirical evidence from structural time series models. Applied Economics, 33(8), 1083-1088. https://doi.org/10.1080/00036840010003276

Owyang, M.T., \& Tatevik, S. (2012). Okun's Law over the Business Cycle: Was the Great

Published by:

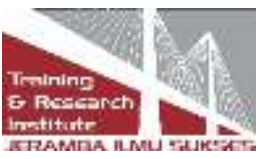


Recession All That Different? Federal Reserve Bank of St. Louis Review, 94(5), 399418.

Moosa, I. A. (1997). A cross-country comparison of Okun's coefficient. Journal of Comparative Economics, 24(3), 335-356.

Nurlanova, N. K., Omarov, A. K., \& Satpayeva, Z. T. (2020). Methodological Approaches to Estimation of Economic Growth and Sustainable Development: Kazakhstan's Experience. Journal of Asian Finance, Economics and Business, 7(4), 317324. https://doi.org/10.13106/jafeb.2020.vol7.no4.317

Okun, A. M. (1962). Potential GNP: Its Measurement and Significance. Proceedings of the Business and Economic Statistics Section, American Statistical Association Washington, D.C., pp. 98-103.

Prabagar, S. (2015). Is Sri Lankan economic behaviours consistent with Okun's Law? International Journal of Accounting \& Business Finance, 1(2), 46-54. available at: http://www.maco.jfn.ac.lk/ijabf/wp-content/uploads/2017/11/Vol1_Issue2_5.pdf

Solow, R. M. (1956). A contribution to the theory of economic growth. The Quarterly Journal of Economics, 70(1), 65-94.

Soylu, O. B., Cakmak, I., \& Okur, F. (2018). Economic growth and unemployment issue: Panel data analysis in Eastern European Countries . Journal of International Studies, 11(1), 93-107.

Wulandari, D., Utomo, H. S., Narmaditya, B. S., \& Kamaludin, M. (2019). Nexus between Inflation and Unemployment: Evidence from Indonesia. Journal of Asian Finance, Economics and Business, 6(2), 269275. https://doi.org/10.13106/jafeb.2019.vol6.no2.269

Zagler, M. ( (2003). The Dynamics of Economic Growth and Unemployment in Major European Countries: Analysis of Okun' s Law. Applied Econometrics and International Development, 3(3). Retrieved from: http://www.usc.es/economet/reviews/aeid336.pdf.

Zonzilos, N. (2000). The Philips Curve of Greek Economy and the Time Variant Nairu. Economic Bulletin in Greek, 15, 15-31.

\section{Copyrights}

Copyright for this article is retained by the author(s), with first publication rights granted to the journal.

It is an open-access article distributed under the terms and conditions of the Creative Commons Attribution license (http://creativecommons.org/licenses/by/4.0/)

Published by: 